\title{
TRANSPORTATION SUSTAINABILITY FRAMEWORK
}

\author{
Kohan Dolcy ${ }^{1}$ and Trevor Townsend ${ }^{2 *}$ \\ ${ }^{1,2}$ Faculty of Engineering, The University of the West Indies, Trinidad and Tobago \\ ${ }^{1}$ Email: kohdolcy@ gmail.com \\ ${ }^{2}$ Email: Trevor.Townsend@sta.uwi.edu*(Corresponding author)
}

\begin{abstract}
Previous research highlighted that the necessary indicators of effectiveness for sustainability are not being measured by the respective stakeholders in Trinidad and Tobago. As with other small island developing states, the country cannot effectively determine its progress towards or away from sustainability. The authors have developed an impact-based hierarchal framework comprising the triple bottom line - economy, environment, and society - and applied it to the local transportation system. Bearing in mind the confines of limited resources and data availability for the Trinidad and Tobago case, the selected indicators were aligned with those used by national, regional and international bodies to monitor sustainability progress, making the framework more useful to stakeholders. Three requirements, nine criteria and 22 indicators were incorporated into the transportation sustainability framework. The authors propose that integrating the necessary data collection and monitoring processes with established tasks already under the purview of the various line ministries can reduce the overall costs of evaluating sustainability progress. Local transportation engineering professionals were surveyed to establish a relative weighting for the key sustainability requirements. They were of the view that the social, environmental and economic sustainability requirements should be weighted at 50\%, 33.3\% and $16.7 \%$ respectively. The professionals also saw potential applications like determining the overall status of and setting targets for improvement to the transportation system, assessing the suitability of proposed alternatives and making decisions about investments in the transport sector. The analytical hierarchy process structure employed in the development of the framework also permits the user to apply their preferred multi-criteria decision making technique based on the alternatives arising and the tolerable degree of compromise.
\end{abstract}

Keywords: Framework, Indicators, Sustainability, Transportation, Trinidad and Tobago.

https://doi.org/10.47412/CVAB8251

\section{Introduction}

Sustainable transportation contributes to and is directly associated with sustainable development goals (SDGs) 3, 7, 9, 11, 12 and 13, which speak to Good Health and Well-Being, Affordable and Clean Energy, Industry, Innovation and Infrastructure, Sustainable Cities and Communities, 
Responsible Consumption and Production and Climate Action. Studies advise that indicators for use in the evaluation of any system must be significant, operational, measurable, and accessible. Evaluation criteria and sustainability indicators identified and applied to transportation systems in the literature are generally categorized into i) economic; ii) environmental; and iii) social impacts $[1,2,3]$. Using a top-down approach, the authors propose that the Trinidad and Tobago transportation sustainability be tackled at a national scale before incorporating other criteria like urban model and freight distribution into the analysis. Commonly applied evaluation approaches employ techniques like descriptive analyses, multi-criteria decision making (MCDM), and 'modeling and simulation'. For this paper, the transportation system will be reviewed according to the analytical hierarchy process (AHP) tree structure proposed by [3], incorporating criteria, indicators and definitions from [1, 2, 4] and ultimately the United Nations SDGs.

\section{Hindrances to Transportation Sustainability in Trinidad and Tobago}

An assessment of the Trinidad and Tobago transportation system by [5] identified some of the issues facing the transportation system sustainability in the country as:

1. National transportation policies are lacking and urgently need to be updated to reflect and address the current local road transportation issues.

2. The roles of transportation planning, transportation demand management, and public transit management are carried out disjointedly by the various stakeholders of the system and are largely influenced by politics, economics and traffic reduction as opposed to the principles of sustainability.

3. The various Joint Select Committees (JSCs) appear to be the most probing bodies with respect to public enquiry. In 2015, the JSC on Land and Physical Infrastructure revealed that a recommendation to define measurable performance indicators for monitoring and evaluating of the performance of the Public Transport Service Cooperation (PTSC), among others, have yet to be implemented.

4. The Trinidadian culture is one of political favour and the population has grown accustomed to large subsidies from successive governments - they have little appreciation for conservation practices and do not recognise the importance of preserving their resources.

5. The Priority Bus Route (PBR) exists and is intended to operate in a manner that will prioritise public transit. However, a limited number of permits are issued to maxi-taxi drivers to access the PBR while it remains accessible to several single occupancy vehicles with valid permits.

6. Expanding the road network without suitable infrastructural upgrades for public transit and non-motorized modes may serve to reduce congestion but will inevitably attract more private transport as opposed to encouraging more sustainable forms of transport. The focus should be on moving people and goods rather than vehicles.

7. The indicators that would assist in determining the sustainability of the transportation system are not being measured by the respective stakeholders. The authors believe that they either have not been identified or the responsibility to collect the data has not been allotted.

8. The country cannot effectively measure its progress toward sustainability due to constraints of data availability and financial resources. In addition, the cost of each endeavour takes precedence over the effects of important issues like sustainability and climate change. 
The above hindrances cannot be overcome on their own and would require the involvement of dedicated professionals in the management of the local transportation system. The tool developed by this paper aims to assist in this regard by providing a means of monitoring, reporting and verifying the sustainability of the transportation system.

\section{Development of Transportation Sustainability Framework}

\subsection{Framework Paradigm}

Modelling of a system requires: i) a set of criteria against which a project's impacts can be measured and evaluated; and ii) a set of balanced indicators that reflect a combination of the system's objectives [6]. "It is important that users understand the perspectives, assumptions, and limitations of each indicator" [6]. Additionally, if the indicators employed would coincide with those used by national, regional and international bodies to monitor sustainability progress, the framework would be more useful to the stakeholders. Integrating the necessary data collection and monitoring processes with established tasks already under the purview of the various line ministries can also reduce the overall costs of evaluating sustainability progress.

An impact-based hierarchal framework comprising the triple bottom line-economy, environment, and society - was applied to the local transportation system, bearing in mind the confines of limited resources and data availability for the Trinidad and Tobago case. Brief definitions of the sustainability requirements are provided to guide the use and application of the road transportation sustainability framework:

- Economic: The economic requirement assesses the current and future states of the transportation system in relation to economic growth, particularly the availability of alternative fuel infrastructure, the price competitiveness on the local market and the ability of individuals to capitalize on the available options.

- Environmental: The environmental requirement focuses on the extraction of resources for input into the transportation system and the resulting outputs which pose threats to human health and to the environment.

- Social: The social requirement explores the aspects of everyday living that can be affected by the operations within the transportation system. These can impact the relationships among people and social institutions such as family, local communities, education and government bodies for example, or even historical and cultural sites [7].

\subsection{Testing and Validation}

An electronic questionnaire was issued to persons identified as transportation professionals, requesting their opinions on the proposed framework. The transportation sustainability requirements, criteria, and indicators were presented, asking the respondents to first rank the three sustainability requirements given a brief description of each. Secondly, the respondents were asked to comment, using a Likert scale, on the suitability of each evaluation criteria and then rank their importance under each of the three sustainability requirements. Lastly, the respondents were asked to comment on the suitability of each indicator, given the definitions from the literature. An 
opportunity was provided for each respondent to either suggest additional indicators or to replace a proposed indicator (with appropriate reference) and or make additional comments.

Eleven responses were received from the 14 potential respondents, representing $78.6 \%$ of the sample. The panel comprised individuals with 3 to 41 years of experience in the areas of traffic and highway engineering, transportation planning and or academia. When asked whether any of the three sustainability requirements identified in the literature should take precedence over another, $54.5 \%$ of the respondents said yes. This is contrary to the equal weightings applied by [1], using the analytic hierarchy process. These individuals labelled the Social requirement as the most important, followed by the Environmental and then the Economic requirements. The suitability of each requirement was not tested as this has been established in the literature.

Commenting on the suitability of the nine proposed criteria, consensus based on a measure of absolute deviation was achieved for all except 'Technology Acceptance'. Notwithstanding, the respondents ranked each of the criteria under each requirement using a modal measure as follows:

a. Social - i) Accessibility and Mobility; ii) Safety; and Technology Acceptance.

b. Environmental - i) Pollution; ii) Energy Efficiency; and iii) Energy Source.

c. Economic - i) Infrastructure; ii) Market Health; and iii) Fuel Price.

Also using the modal measure, relative weightings were applied to each requirement and criteria within the framework. The individual level 1 and level 2 weightings were multiplied to obtain a relative weighting for each criterion. The importance weighting of each criterion as derived from the authors' analysis of the modal responses is shown in

Figure 2. Note that Technology Acceptance was retained as a criterion since the associated indicator gained consensus as suitable.

Commenting on the suitability of the 21 proposed indicators, the absolute deviation of the responses was used as a measure of consensus. Twenty (20) indicators achieved consensus and were deemed suitable, the 


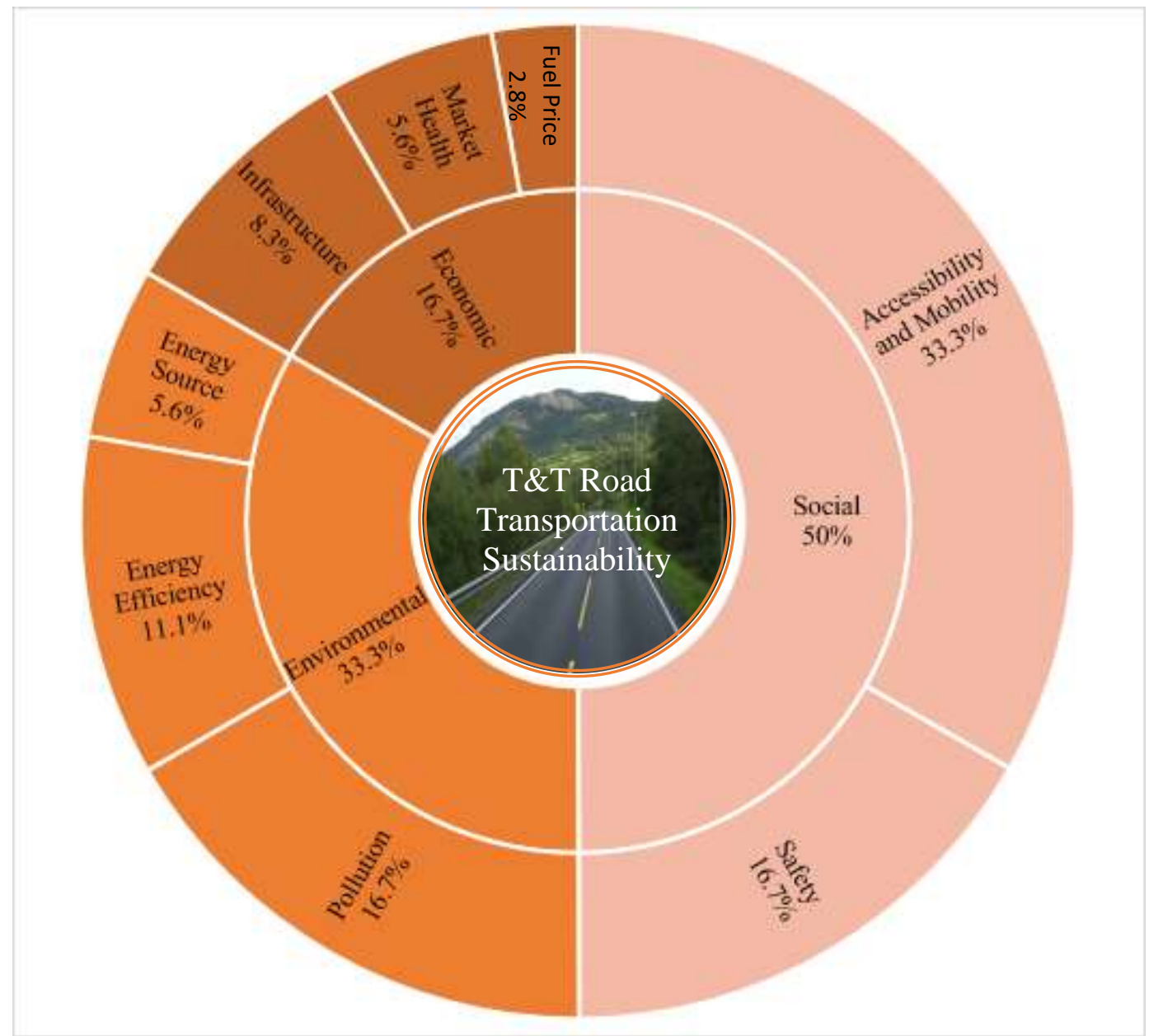

Figure 2. Importance weighting of each sustainability requirement and criterion [5]

exception being Ec2.4 - 'Unemployment'. Although indicator Ec2.1 - 'Average earnings' was deemed suitable, one respondent recommended that it be replaced by 'Fuel cost per kilometre as a percentage average daily earnings'. Conversely, indicator Ec2.4 was deemed not suitable and 'Disposable Income was suggested as a replacement. Given the authors' intention to utilize indicators for which information would be readily available, the former recommendation can be considered alongside the existing. The latter is dependent on average earnings and is therefore already reflected within the framework. Other indicators suggested for inclusion by one of the participants are: a) 'Percentage of non-motorized mode use'; b) 'Frequency of non-motorized transport', and c) 'Accidents involving non-motorized transport'. Suggestions a) and c) were also employed by [1] and were therefore included in the framework under the criteria 'So1 Accessibility and Mobility' and 'So2 - Safety' respectively. A means of collecting data for suggestion b) would need to be developed prior to incorporating into the proposed framework. The hierarchal framework for the Trinidad and Tobago road transportation system is shown in Figure 3. 
When asked whether the proposed framework would be useful in their areas of work, 10 of the 11 respondents said yes and one responded with 'maybe'. The respondents generally found that the framework would be very useful in transportation and decision making, with potential applications such as:

i. Determining the overall status of the transportation system;

ii. Setting targets for improvements to the transportation system;

iii. Assessing the suitability of proposed alternatives; and

iv. Making decisions about investments in the transport sector. 


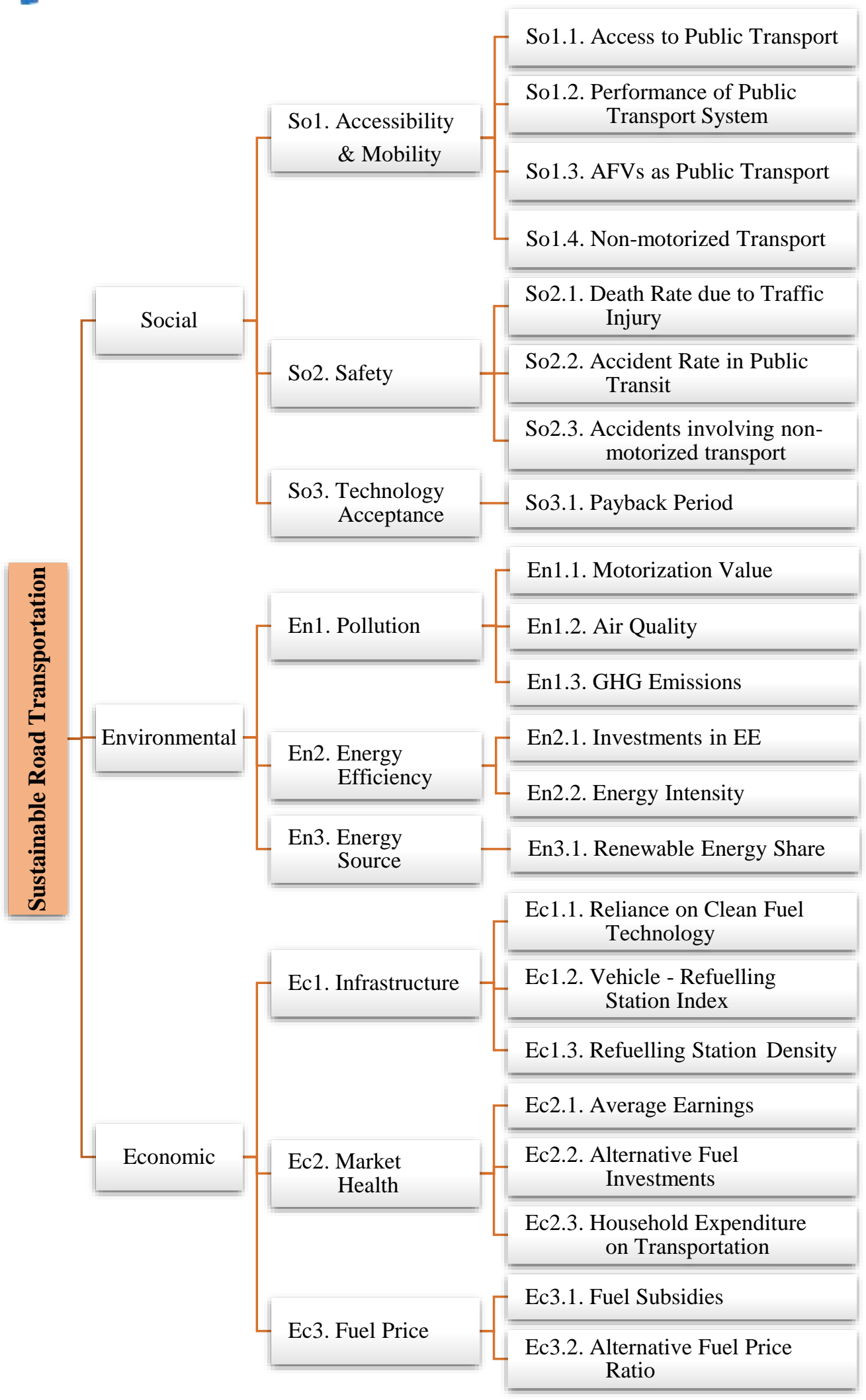

Figure 3. Transportation sustainability framework for Trinidad and Tobago 


\subsection{Framework Summary}

Also using the modal measure, relative weightings were applied to each requirement and criteria within the framework. The individual level 1 and level 2 weightings were multiplied to obtain a relative weighting for each criterion. The importance weighting of each criterion as derived from the authors' analysis of the modal responses is shown in

Figure 2. Note that Technology Acceptance was retained as a criterion since the associated indicator gained consensus as suitable. presents the proposed criteria and the various indicators deemed relevant to road transportation sustainability. References, definitions, and units of measurement for each of the proposed indicators are also identified, stating the available values for the period 2014 to 2018 . The framework contains 3 requirements, 9 criteria and 22 indicators that are intended for use by both decision-makers and planners, locally and internationally, to measure, report and monitor sustainability progress and or to identify ways to improve the transportation system. The AHP structure employed also permits the user to apply their preferred MCDM technique or modelling approach based on the alternatives arising and the tolerable degree of compromise.

\section{Conclusion}

The 'Road Transportation Sustainability Framework' for Trinidad and Tobago is presented in Figure 3 . The 22 emerging indicators can be evaluated within the framework, to explore the effect of emerging policy and planned projects on the system sustainability. The framework can be used primarily as a guide in informing of the requirements for the sustainability of the transportation system. It can also play an integral role in the evaluation of alternative solutions to transportation problems while guiding the actions of the Ministry of Works and Transport (MOWT) and other stakeholders. Local transportation professionals acknowledge the usefulness of the framework in planning, assessing and or selecting alternative fuel investment options.

\section{Recommendations and Future Work}

The authors recommend that the following actions be carried out in tandem with or to facilitate initiatives like the implementation of alternative fuel vehicles (AFVs) for improved sustainability:
a. Data Collection, Research and Development Programs;
b. Behavioural Change;
c. Political Efforts;
d. High Occupancy and Clean Vehicle Priority;
e. Adequate Public Transportation Services;
f. Intracity Transit;
g. Energy Efficiency; and
h. Renewable Energy.

Implementation of the above recommendations requires collection of the necessary data and increased infiltration of AFVs into the Trinidad and Tobago transportation system. Application of 
the sustainability framework using either an MCDM or modelling approach can then provide quantitative feedback on the sustainability progress. The various existing policies incentives can be revised and tested to chart the course for more objective transportation investments to enhance sustainability over the next decade. Development of a VCI [vehicle-charging station] index for electric vehicle penetration should also be explored to avoid a similar chicken and egg conundrum for this new AFV technology. 
Table 1. Transportation sustainability indicators, descriptions and values (where available) for the years 2014 to 2018 [5]

\begin{tabular}{|c|c|c|c|c|c|c|c|c|c|c|}
\hline Code & $\begin{array}{l}\text { Indicator } \\
\text { Reference }\end{array}$ & Description & 2014 & $\begin{array}{l}201 \\
5\end{array}$ & $\begin{array}{l}201 \\
6\end{array}$ & 2017 & 2018 & Unit & Limits & $\begin{array}{l}\text { Comments/ } \\
\text { Probable Data } \\
\text { Source }\end{array}$ \\
\hline \multirow{2}{*}{$\begin{array}{l}\text { So1. } \\
1\end{array}$} & SDGI 112.1 & $\begin{array}{l}\text { Proportion of the population that } \\
\text { has convenient access to public } \\
\text { transport (by sex, age and persons } \\
\text { with disabilities) }\end{array}$ & & & & & $>85$ & $\%$ & & \\
\hline & $\begin{array}{l}\text { Author } \\
\text { proposed }\end{array}$ & $\begin{array}{l}\text { Proportion of the elderly and } \\
\text { disabled population serviced by } \\
\text { ELDAMO [reduction factor] }\end{array}$ & & & & & - & $\%$ & & \\
\hline \multirow{2}{*}{$\begin{array}{l}\text { So1. } \\
2\end{array}$} & \multirow{2}{*}[8]{} & $\begin{array}{l}\text { Number of passenger trips by } \\
\text { public transit }\end{array}$ & & & & & - & no. & & $\begin{array}{l}\text { PTSC, AMTTT or } \\
\text { collect data }\end{array}$ \\
\hline & & $\begin{array}{l}\text { Vehicle kilometres travelled (vkt) } \\
\text { by public transit }\end{array}$ & & & & & - & vkt & & $\begin{array}{l}\text { PTSC, AMTTT or } \\
\text { collect data }\end{array}$ \\
\hline $\begin{array}{l}\text { So1. } \\
3\end{array}$ & $\begin{array}{l}\text { Author } \\
\text { proposed }\end{array}$ & $\begin{array}{l}\text { Proportion of AFVs belonging to } \\
\text { the population of vehicles } \\
\text { providing public transport }\end{array}$ & 0.18 & & & & 0.84 & $\%$ & & \\
\hline $\begin{array}{l}\text { So1. } \\
4\end{array}$ & $\begin{array}{l}\text { Panel } \\
\text { proposed, } \\
{[1]}\end{array}$ & $\begin{array}{l}\text { Percentage of non-motorized } \\
\text { mode use }\end{array}$ & $\begin{array}{l}0.00 \\
3\end{array}$ & & & $\begin{array}{l}0.01 \\
3^{1}\end{array}$ & - & $\%$ & & $\begin{array}{l}\text { CSO survey data or } \\
\text { other transport study }\end{array}$ \\
\hline
\end{tabular}

\footnotetext{
${ }^{1}$ Using 'other' category from Ministry of Works and Transport (MOWT) data
} 
The International Conference on Emerging Trends in Engineering and Technology (IConETech-2020)

Faculty of Engineering, The UWI, St. Augustine | June $1^{\text {st }}-5^{\text {th }}, 2020$

\begin{tabular}{|c|c|c|c|c|c|c|c|c|c|c|}
\hline Code & $\begin{array}{l}\text { Indicator } \\
\text { Reference }\end{array}$ & Description & 2014 & $\begin{array}{l}201 \\
5\end{array}$ & $\begin{array}{l}201 \\
6\end{array}$ & 2017 & 2018 & Unit & Limits & $\begin{array}{l}\text { Comments/ } \\
\text { Probable Data } \\
\text { Source }\end{array}$ \\
\hline $\begin{array}{l}\text { So2. } \\
1\end{array}$ & SDGI 3.6.1 & $\begin{array}{l}\text { Death rate due to road traffic } \\
\text { injuries (per } 100,000 \text { population) }\end{array}$ & $\begin{array}{l}11.8 \\
2\end{array}$ & 9.12 & 8.06 & 7.66 & 7.99 & & & $\begin{array}{l}\text { Local data low } \\
\text { compared to UN } \\
\text { database; no data in } \\
\text { the latter source for } \\
\text { given period }\end{array}$ \\
\hline $\begin{array}{l}\text { So2. } \\
2\end{array}$ & $\begin{array}{l}\text { Author } \\
\text { proposed }\end{array}$ & $\begin{array}{l}\text { Number of accidents involving } \\
\text { vehicles providing public } \\
\text { transport per year }\end{array}$ & 316 & & & & - & no. & & $\begin{array}{l}\text { PTSC, AMTTT, } \\
\text { TTPS }\end{array}$ \\
\hline $\begin{array}{l}\text { So2. } \\
3\end{array}$ & $\begin{array}{l}\text { Panel } \\
\text { proposed, } \\
{[1]}\end{array}$ & $\begin{array}{l}\text { Vehicle accidents involving } \\
\text { pedestrians and or bicycles }\end{array}$ & & & & & & no. & & TTPS \\
\hline $\begin{array}{l}\text { So3. } \\
1\end{array}$ & {$[4,9,10]$} & $\begin{array}{l}\text { The amount of the initial } \\
\text { investment in relation to the } \\
\text { annual savings (in fuel) afforded } \\
\text { by the alternative fuel technology }\end{array}$ & & & & & & $\begin{array}{l}\text { year } \\
\text { s }\end{array}$ & $3-4$ & \\
\hline $\begin{array}{l}\text { En1. } \\
1\end{array}$ & {$[1]$} & Ratio of vehicles to inhabitants & 0.59 & 0.61 & 0.63 & 0.64 & - & $\%$ & & $\begin{array}{l}\text { MOWT vehicle } \\
\text { estimates and WB } \\
\text { population data }\end{array}$ \\
\hline $\begin{array}{l}\text { En1. } \\
2\end{array}$ & $\begin{array}{l}\text { SDGI 9.4.1, } \\
{[1]}\end{array}$ & $\begin{array}{l}\mathrm{CO}_{2} \text { emissions per unit of value } \\
\text { added }(\mathrm{kg} \text { per } 2010 \mathrm{US} \$ \text { of GDP } \\
\text { in 2014) }\end{array}$ & $\begin{array}{l}2.05 \\
3\end{array}$ & & & & & & $\begin{array}{l}\text { LAC } \\
\text { aggregate - } \\
0.321 ; \\
\text { World } \\
\text { aggregate - } \\
0.491\end{array}$ & \\
\hline
\end{tabular}


The International Conference on Emerging Trends in Engineering and Technology (IConETech-2020)

Faculty of Engineering, The UWI, St. Augustine | June $1^{\text {st }}-5^{\text {th }}, 2020$

\begin{tabular}{|c|c|c|c|c|c|c|c|c|c|c|}
\hline Code & $\begin{array}{l}\text { Indicator } \\
\text { Reference }\end{array}$ & Description & 2014 & $\begin{array}{l}201 \\
5\end{array}$ & $\begin{array}{l}201 \\
6\end{array}$ & 2017 & 2018 & Unit & Limits & $\begin{array}{l}\text { Comments/ } \\
\text { Probable Data } \\
\text { Source }\end{array}$ \\
\hline $\begin{array}{l}\text { En1. } \\
3\end{array}$ & $\begin{array}{l}\text { SDGI } \\
11.6 .2,[1, \\
2]\end{array}$ & $\begin{array}{l}\text { Annual mean levels of fine } \\
\text { particulate matter in cities } \\
\text { (population weighted) }\end{array}$ & & & & & & & & \\
\hline $\begin{array}{l}\text { En2. } \\
1\end{array}$ & SDGI 7.b.1 & $\begin{array}{l}\text { Investments in energy efficiency } \\
\text { as a percentage of GDP and the } \\
\text { amount of foreign direct } \\
\text { investment in financial transfer } \\
\text { for infrastructure and technology } \\
\text { to sustainable development. }\end{array}$ & 66.7 & 66.7 & 50.5 & 43.5 & 29.3 & $\%$ & & \\
\hline $\begin{array}{l}\text { En2. } \\
2\end{array}$ & $\begin{array}{l}\text { SDGI 7.3.1, } \\
{[1]}\end{array}$ & $\begin{array}{l}\text { Energy intensity measured in } \\
\text { terms of primary energy and } \\
\text { GDP; }\end{array}$ & & & & & - & $\%$ & & \\
\hline $\begin{array}{l}\text { En3. } \\
1\end{array}$ & SDGI 7.2.1 & $\begin{array}{l}\text { Renewable energy share in the } \\
\text { total final energy consumption }\end{array}$ & & & & & 0.3 & $\%$ & & \\
\hline $\begin{array}{l}\text { Ec1. } \\
1\end{array}$ & SDGI 7.12. & $\begin{array}{l}\text { Proportion of the population with } \\
\text { primary reliance on clean fuels } \\
\text { and technology }\end{array}$ & $>95$ & $>95$ & $>95$ & $>95$ & $>95$ & $\%$ & & \\
\hline Ec1.2 & [9] & $\begin{array}{l}\text { Ratio of AFVs (in thousands) to } \\
\text { the number of alternative fuel } \\
\text { refueling stations }\end{array}$ & & & & & $\begin{array}{l}0.67 \\
0.00 \\
7\end{array}$ & $\%$ & $\begin{array}{l}\text { Optimal } \\
\text { value of } 1 ; \\
\text { Min. of } 0.2 \text {; } \\
\text { Max. of } 1.1 \\
-1.3\end{array}$ & \\
\hline Ec1.3 & {$[2,4]$} & $\begin{array}{l}\text { Ratio of alternative fuel refuelling } \\
\text { stations to gasoline refuelling } \\
\text { stations }\end{array}$ & & & & & $\begin{array}{l}0.08 \\
0.02 \\
9\end{array}$ & $\%$ & $\begin{array}{l}\text { Min. of } 0.1 \\
-0.2\end{array}$ & \\
\hline
\end{tabular}


The International Conference on Emerging Trends in Engineering and Technology (IConETech-2020)

Faculty of Engineering, The UWI, St. Augustine | June $1^{\text {st }}-5^{\text {th }}, 2020$

\begin{tabular}{|c|c|c|c|c|c|c|c|c|c|c|}
\hline Code & $\begin{array}{l}\text { Indicator } \\
\text { Reference }\end{array}$ & Description & 2014 & $\begin{array}{l}201 \\
5\end{array}$ & $\begin{array}{l}201 \\
6\end{array}$ & 2017 & 2018 & Unit & Limits & $\begin{array}{l}\text { Comments/ } \\
\text { Probable Data } \\
\text { Source }\end{array}$ \\
\hline Ec2.1 & SDGI 8.5.1 & $\begin{array}{l}\text { Average hourly earnings (by sex, } \\
\text { occupation, age and persons with } \\
\text { disabilities - if available) }\end{array}$ & & & & & & $\%$ & & \\
\hline Ec2.2 & $\begin{array}{l}\text { Author } \\
\text { proposed }\end{array}$ & $\begin{array}{l}\text { Government expenditure on } \\
\text { alternative fuel investments }\end{array}$ & & & & & $\begin{array}{l}129 \\
\text { mill }\end{array}$ & $\%$ & & \\
\hline Ec2.3 & {$[11]$} & $\begin{array}{l}\text { Percentage of household earnings } \\
\text { spent on transportation }\end{array}$ & & & & & - & $\%$ & $15 \%-20 \%$ & \\
\hline Ec3.1 & $\begin{array}{l}\text { SDGI } \\
\text { 12.c. } 1\end{array}$ & $\begin{array}{l}\text { Amount of fossil-fuel subsidies } \\
\text { per unit of GDP (production and } \\
\text { consumption) and as a proportion } \\
\text { of total national expenditure on } \\
\text { fossil fuels }\end{array}$ & & & & 0.2 & - & $\begin{array}{l}\% \\
\mathrm{GD} \\
\mathrm{P}\end{array}$ & & \\
\hline \multirow[t]{2}{*}{ Ec3.2 } & \multirow[t]{2}{*}[4]{} & \multirow{2}{*}{$\begin{array}{l}\text { Ratio of the price of the } \\
\text { alternative fuel to the price of the } \\
\text { conventional fuel }\end{array}$} & 37.0 & 32.2 & 27.9 & 25.2 & 20.1 & \multirow[t]{2}{*}{$\%$} & $\begin{array}{l}40 \%-60 \%- \\
\text { gasoline } \\
\text { (wrt CNG) }\end{array}$ & \\
\hline & & & 66.7 & 66.7 & 50.5 & 43.5 & 29.3 & & $\begin{array}{l}70 \% \text { - diesel } \\
\text { (wrt CNG) }\end{array}$ & \\
\hline
\end{tabular}




\section{References}

[1] U. Oses, E. Roji, J. Cuadrado, and M. Larrauri, "Multiple-Criteria Decision-Making Tool for Local Governments to Evaluate the Global and Local Sustainability of Transportation Systems in Urban Areas: Case Study," Journal of Urban Planning and Development, vol. 144, no. 1, pp. 117, 2017.

[2] M. Yavuz, B. Oztaysi, S. C. Onar, and C. Kahraman, "Multi-criteria evaluation of alternativefuel vehicles via a hierarchical linguistic model," Expert Systems with Applications, vol. 42, pp. 2835-2848, 2014.

[3] J. M. Ngossaha, R. H. Ngouna, B. Archimède, and J. M. Nlong, "Sustainability assessment of a transportation system under uncertainty: an integrated multicriteria approach," IFACPapersOnLine, vol. 50, no. 1, pp. 7481-7489, 2017.

[4] S. Yeh, "An empirical analysis on the adoption of alternative fuel vehicles: The case of natural gas vehicles," Energy Policy, vol. 35, no. 11, pp. 5865-5875, 2007.

[5] K. Dolcy, "Alternative Fuel Vehicles for the Sustainability of the Transportation System - A Study of Trinidad and Tobago," Master of Science in Civil Engineering, Department of Civil and Environmental Engineering, The University of the West Indies, 2019.

[6] T. Litman, "Developing Indicators for Comprehensive and Sustainable Transport Planning," Journal of the Transportation Research Board, vol. 2017, no. 02, pp. 10-15, 2007.

[7] E. Cascetta, Transportation Systems Analysis: Models and Applications. New York: New York, NY: Springer, 2009.

[8] Rationalisation of the PTSC Bus Fleet Committee, "Rationalisation of the Public Transport Service Corporation (PTSC) Bus Fleet - Final Report Executive Summary," PTSC, Port of Spain, Trinidad and Tobago, 2014.

[9] A. Janssen, S. F. Lienin, F. Gassmann, and A. Wokaun, "Model aided policy development for the market penetration of natural gas vehicles in Switzerland," Transportation Research Part A: Policy and Practice, vol. 40, no. 4, pp. 316-333, 2006.

[10] C. Nwaoha and U. J. Iyoke, "A Review on Natural Gas Utilization and Cutting Carbon Emissions: How viable is Compressed Natural Gas for Road Vehicle Fuel?," Journal of Energy Technologies and Policy, vol. 3, no. 5, pp. 37-46, 2013.

[11] R. Buehler, J. Pucher, and U. Kunert, "Making Transportation Sustainable; Insights from Germany," Brookings Institution Metropolitan Policy Program, Washington D.C., 2009, Available: content/uploads/2016/06/0416_germany_transportation_report.pdf.

https://www.brookings.edu/wp- 